\title{
Pemasaran Interaktif melalui Media Sosial sebagai Sarana Promosi Applecoast Clothing
}

\author{
Surya Ramadiansyah *, Dede Lilis Chaerowati \\ Prodi Manajemen Komunikasi, Fakultas Ilmu Komunikasi, Universitas Islam \\ Bandung, Indonesia. \\ *suryard95@gmail.com, dede.lilis@unisba.ac.id
}

\begin{abstract}
Social media in marketing is useful as a medium for promoting brands, building preferences and increasing sales through various digital marketing techniques. Applecoast is a retail and e-commerce based fashion company. In its marketing activities, Applecoast does a variety of ways and one of them uses social media as one of its main promotional media. This research uses a quantitative approach with descriptive methods. The population is 11,900 Applecoast Instagram followers who live in the city of Bandung. A sample of 100 respondents were selected through the Systematic Random Sampling technique. Data collection techniques are done through questionnaires, interviews, and literature study. Data analysis techniques consisted of validity and reliability tests. The results showed that the application of social media marketing 4C (context, communication, collaboration, and connection) conducted by Applecoast had not been maximized. Based on the results of the study, the application of the context or use of language and message content is in the unfavorable category. The application of communication or the process of delivering information is quite well done. Implementation of collaboration or forms of collaboration are quite good. And the application of the connection or in maintaining relationships that have been established quite well done. The research method used is descriptive-quantitative because research is conducted to determine the existence of an independent variable, only on one variable. The population is collected through questionnaires. The data analysis technique uses quantitative analysis of interval assessments.
\end{abstract}

Keywords: context, communication, collaboration, connection, social media, and Instagram.

\begin{abstract}
Abstrak. Media sosial dalam pemasaran berguna sebagai media untuk mempromosikan merek, membangun prefensi dan meningkatkan penjualan melalui berbagai macam teknik pemasaran digital. Applecoast merupakan salah satu perusahaan fashion berbasis retail dan e-commerce. Dalam Kegiatan pemasaranya, Applecoast melakukan berbagai cara dan salah satunya menggunakan media sosial sebagai salah satu media promosi utamanya. Penelitian ini menggunakan pendekatan kuantitatif dengan metode deskriptif. Populasi berjumlah 117.00 followers instagram Applecoast yang berdomisili di Kota Bandung. Sample berjumlah 100 orang responden yang dipilih melalui teknik Systematic Random Sampling. Teknik pengumpulan data dilakukan melalui kuesioner, wawancara, dan studi pustaka. Teknik analisis data terdiri dari uji validitas dan uji reliabilitas.Hasil penelitian menunjukan bahwa penerapan sosial media marketing 4C(context, communication, collaboration, dan connection) yang dilakukan Applecoast belum maksimal. Berdasarkan dari hasil penelitian, penerapan context atau penggunaan bahasa dan isi pesan berada dalam dalam kategori kurang baik. Penerapan communication atau proses penyampaian informasi cukup baik dilakukan. Penerapan collaboration atau bentuk kerjasama yang dilakukan cukup baik. Dan penerapan connection atau dalam memelihara hubungan yang sudah terjalin cukup baik dilakukan. Metode penelitian yang digunakan yaitu deskriptif-kuantitatif karena penelitian yang dilakukan untuk mengetahui keberadaan variabel mandiri, hanya pada satu variabel. Populasinya dengan teknik pengumpulan melalui kuesioner. Teknik analisis data menggunakan analisis kuantitatif interval penilaian.
\end{abstract}

Kata Kunci: context, communication, collaboration, connection, media sosial, dan instagram. 


\section{A. Pendahuluan}

Pada era digital saat ini media sosial adalah salah satu perkembangan teknologi yang memiliki andil besar dalam memberikan kemudahan bagi manusia untuk berkomunikasi dan bersosialisasi.

Fenomena tersebut merupakan peluang besar bagi para produsen yang menawarkan kemudahan kepada konsumen untuk menjual produknya melalui internet terutama media sosial. Proses transaksi jual beli dapat dilakukan dengan mudah dalam penggunaan internet.

Mengingat saat ini popularitas media sosial dapat mempermudah produsen dalam mempromosikan produknya. Selain itu para produsen dapat berkreasi sekreatif mungkin di media sosial dengan tujuan untuk menarik minat beli konsumen. Karena secara logis jika pemanfaatan media sosial yang baik akan mempengaruhi minta beli konsumen.

Penggunaan media sosial sendiri sangat berguna sekali bagi para pelaku bidang industri kreatif. Industri kreatif dipercaya pemerintah sebagai salah satu harapan bagi ekonomi Indonesia untuk bangkit, bersaing dan meraih keunggulan dalam ekonomi global. Perkembangan industri kreatif Kota Bandung menjadi salah satu percontohan dalam pengembangan ekonomi kreatif yang melibatkan komunitas secara aktif. Semakin pesatnya perkembangan usaha fashion di Kota Bandung semakin ketat juga tingkat persaingan dan kondisi ketidakpastian di dunia bisnis fashion maka produk yang diciptakan harus inovatif dan kreatif dalam menghasilkan produk.

Applecoast merupakan salah satu clothing brand yang berbasis retail dan ecommerce yang berasal dari Bandung terbentuk pada 20 April 2013. Applecoast ini menyasar segmentasi produknya untuk para pria. Produk ini bergerak di culture streetwear atau culture jalanan yang mengarah ke extreme sport. Produk yang bergerak di bidang apparel ini menjual beragam brand fashion seperti topi, kemeja, kaos, tas, kaos kaki, dompet, dan sweater. Applecoast juga beralamat di jalan Cikutra no. 205 Bandung.

Masalah yang muncul pada Applecoast ini diidentifikasi bahwa adanya penurunan minat beli ulang oleh pelanggan, hal ini diperkuat karena banyaknya pesaing dan adanya orang - orang kreatif yang menjadi alasan distro Applecoast mengandalkan promosi diwaktu waktu tertentu untuk menarik konsumen dan meningkatkan pembelian terhadap produk.

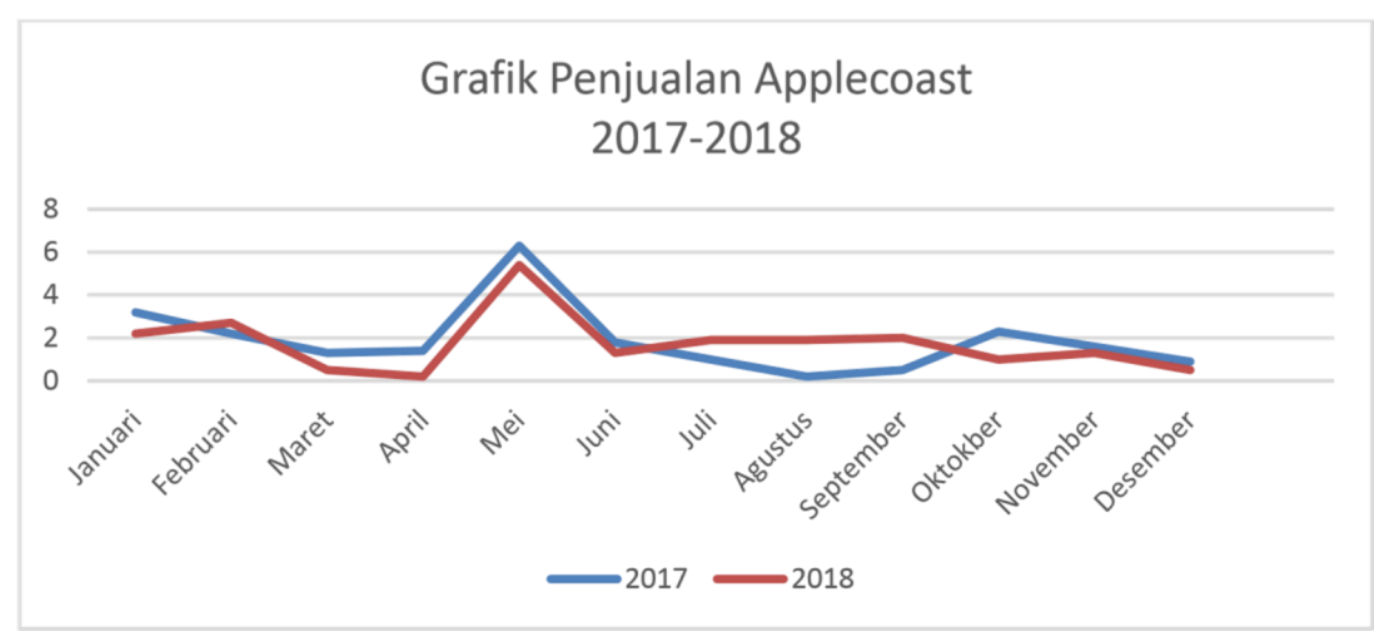

\section{Sumber : Applecoast Clothing}

Gambar 1. Data Penjualan Applecoast Clothing Tahun 2017-2018

Berdasarkan tabel grafik di atas menunjukan bahwa pendapatan cenderung mengalami penurunan. Penuruan terjadi dari tahun 2017 ke 2018, jika adanya penurunan jumlah pembeli mengidikasikan bahwa adanya penurunan minat beli ulang pelanggan, hal ini disebabkan oleh adanya faktor - faktor yang mempengaruhi minat beli ulang pembeli di Applecoast. Salah satu 
faktor yang mempengaruhi ialah kurangnya promosi melalui media sosial. Salah satu penggunaan promosi Applecoast adalah sosial media Instagram. Berikut adalah Instagram Applecoast @applecoast.

Pentingnya pemahaman mengenai upaya dalam penerapan sosial media marketing sebagai sarana promosi menjadi bagian yang mendapat perhatian penting dalam penelitian ini. Dengan demikian peneliti akan mengkaji Pemasaran Interaktif Melalui Media Sosial Sebagai Sarana Promosi Applecoast Clothing.

\section{B. Landasan Teori}

Teori respon kognitif menunjukkan bahwa terpaan media yang diterima khalayak akan disortir dengan mengevaluasinya terlebih dahulu sebagaimana diungkapan oleh E. Belch dan A. Belch dalam Rosmawan (2016: 11) bahwa, "Khalayak secara aktif terlibat dalam proses penerimaan informasi dengan cara mengevaluasi informasi yang diterima berdasarkan pengetahuan dan sikap yang dimiliki sebelumnya, yang akhirnya mengarah pada perubahan sikap."

Teori respon kognitif menunjukkan bahwa khalayak memiliki caranya sendiri dalam menilai berbagai isi pesan yang disajikan media. Terkait dengan pesan - pesan yang bersifat persuasif, teori respon kognitif menunjukkan bahwa pesan - pesan tersebut dapat menentukan sikap dan arah perubahan perilaku setelahnya.

Teori respon kognitif meliputi kegiatan - kegiatan mental yang sadar seperti berpikir, mengetahui, memahami, dan kegiatan konsepsi mental seperti: sikap, kepercayaan, dan pengharapan, yang kemudian itu merupakan factor yang menentukan di dalam perilaku. Di dalam teori ini terdapat suatu interest yang kuat dalam menjawab respons atas akibat dari perilaku yang tertutup. Karena di dalam hal ini sulit mengamati secara langsung proses berfikir dan pemahaman, dan juga sulit menyentuh dan melihat sikap, nilai, dan kepercayaan.

\section{Komunikasi}

Komunikasi merupakan salah satu prasyarat dalam kehidupan manusia. Kehidupan manusia akan terasa hampa apabila tidak ada komunikasi. Karena manusia merupakan makhluk sosial selain itu tanpa komunikasi, interaksi antar manusia baik secara perorangan, kelompok, atau organisasi tidak akan terjadi.

Carl I. Hovland mengemukakan bahwa komunikasi adalah " proses mengubah perilaku orang lain (Communication is the process to modify the behavior of other individuality) "(Uchjana, 2016: 9). Berdasarkan definisi tersebut yang menjadi sorotan Hovland bukan hanya pada penyampaian informasi, melainkan juga pembentukan pendapat umum, dan sikap public yang dalam kehidupan sosial merupakan sebuah peran yang amat sangat penting.

Untuk memahami pengertian komunikasi banyak sekali para pakar komunikasi mengutip paradigma yang dikemukakan oleh Harold Lasswell. Menurut Lasswell (Uchjana, 2016:10) " cara yang baik untuk menjelaskan komunikasi ialah menjawab pertanyaan sebagai berikut: "Who Says What In Which Channel To Whom With What Effect? ".

Paradigma Lasswell tersebut menunjukkan bahwa komunikasi meliputi lima unsur sebagai jawaban dari pertanyaan yang diajukan, yaitu:

1. Komunikator

2. Pesan

3. Media

4. Komunikan

5. Efek

\section{Komunikasi Pemasaran}

Komunikasi menjadi dasar dari pentingnya penyampaian pesan dalam pemasaran yang dipegunakan untuk membangun dialog hingga menumbuhkan hubungan yang bersifat menguntungkkan sebagaimana apa yang diungkapan Kotler dan Keller dalam Indika dan Jovita (2017: 26) bahwa: Komunikasi pemasaran merupakan cara - cara yang dilakukan perusahaan untuk dapat berinteraksi baik dengan pihak-pihak internal perusahaan (karyawan) maupun eksternal (konsumen, pemerintah, pesaing ,dll) dengan tujuan meningkatkan citra 
perusahaan".

Komunikasi memiliki peran penting dalam pemasaran, karena hubungan antara produsen dan konsumen harus terjalin dengan baik, seperti apa yang diungkapkan Triwardhani dan Gartanti (2018: 68) bahwa : Komunikasi bukan hanya bagaimana proses penyampaian pesan, tetapi juga di mana komunikator dapat menjadi pendengar yang baik bagi komunikan. Kemampuan untuk mendengarkan diperlukan untuk memahami apa yang diinginkan oleh konsumen atau mitra bisnis, sehingga mereka merasa bahwa kebutuhan mereka terpenuhi dan ingin kembali ketika membutuhkan. pesannya lebih terkait dengan produk, harga, kemasan, dan lain-lain.

\section{Promosi}

Kegiatan pemasaran tidak terlepas dari promosi. Menurut Alma dalam Daud (2013: 52) "Promosi adalah jenis komunikasi yang memberi penjelasan yang meyakinkan calon konsumen tentang barang dan jasa. Hal ini bertujuan untuk perhatian, mendidik, mengingatkan, dan meyakinkan calon konsumen". Sementara menurut Mc-Daniel dalam Wolah (2016: 2) mengatan bahwa "Promosi adalah komunikasi dari para penjual yang menginformasikan, membujuk, dan meningkatkan para calon pembeli suatu produk dalam rangka mempengaruhi pendapat mereka atau memperoleh suatu respon".

Promosi menunjuk pada berbagai aktivitas yang dilakukan perusahaan untuk mengkomunikasikan keunggulan produknya dan membujuk para pelanggan dan konsumen sasaran untuk membeli produk tersebut. Kegiatan promosi penting dilakukan, hal tersebut karena di zaman seperti ini jarak antara produsen dan konsumen yang bertambah jauh dan jumlah konsumen potensial yang bertambah banyak. Kegiatan promosi dapat dilakukan dengan berbagai cara dan salah satunya melalui media, terutama media social.

\section{Sosial Media Marketing}

Kegiatan pemasaran mengalami perubahan signifikan berkat kehadiran media sosial. Hal tersebut dikarenakan dengan adanya media sosial kegiatan pemasaran lebih mudah dilakukan tak terhalang ruang dan waktu. Media sosial mencerminkan berbagi sumber baru informasi online yang diciptakan, disirkulasikan, dan digunakan oleh konsumen dengan tujuan untuk saling mengedukasi tentang produk, merek, jasa dalam sebuah pemasaran, Pada hakikatnya media sosial adalah teknologi berbasis internet yang memfasilitasi percakapan. (Tjiptono 2015: 395)

Para produsen wajib memanfaatkan media sosial secara cermat. Hal ini dikarenakan media sosial memiliki dua peran penting yang saling terikat. Pertama, media sosial memungkinkan perusahaan untuk berkomunikasi dengan pelanggan. Kedua, media sosial dapat dimanfaatkan oleh pelanggan untuk berkomunikasi dengan sesama pelanggan. (Tjiptono 2015: 396)

Dalam penyampaian komunikasi pemasaran melalui media sosial dapat dinilai melalui 4C, yaitu context, Communication, Collaboration, dan connection (Hauer, dalam Indika dan Jovita 2017). Context adalah "how we frame our stories" yaitu cara bagaimana seseorang membentuk suatu cerita melalui penggunaan bahasa dan isi pesan. Communication adalah "the practice of sharing our sharing story as well as listening, responding, and growing," yaitu cara bagaimana berbagi cerita membuat seseorang mendengar, merespon, dan tumbuh sehingga orang menjadi nyaman dan pesan tersampaikan kepada orang yang dituju. Collaboration adalah "working together to make things better and more efficient and effective". Kerja sama yang dimaksud adalah kerja sama antara akun atau perusahaan dengan pengguna media sosial yang bertujuan membuat hal menjadi lebih baik, lebih efisien, dan lebih efektif. Connection adalah "the relationship we forge and maintain" yaitu cara bagaimana mempertahankan dan terus mengembangkan hubungan yang telah dilakukan.

\section{Kerangka Pemikiran}

Berdasarkan pemaparan pemikiran di atas mengenai kerangka pemikiran maka didapatkanlah gambaran kerangka pemikiran sebagai berikut: 


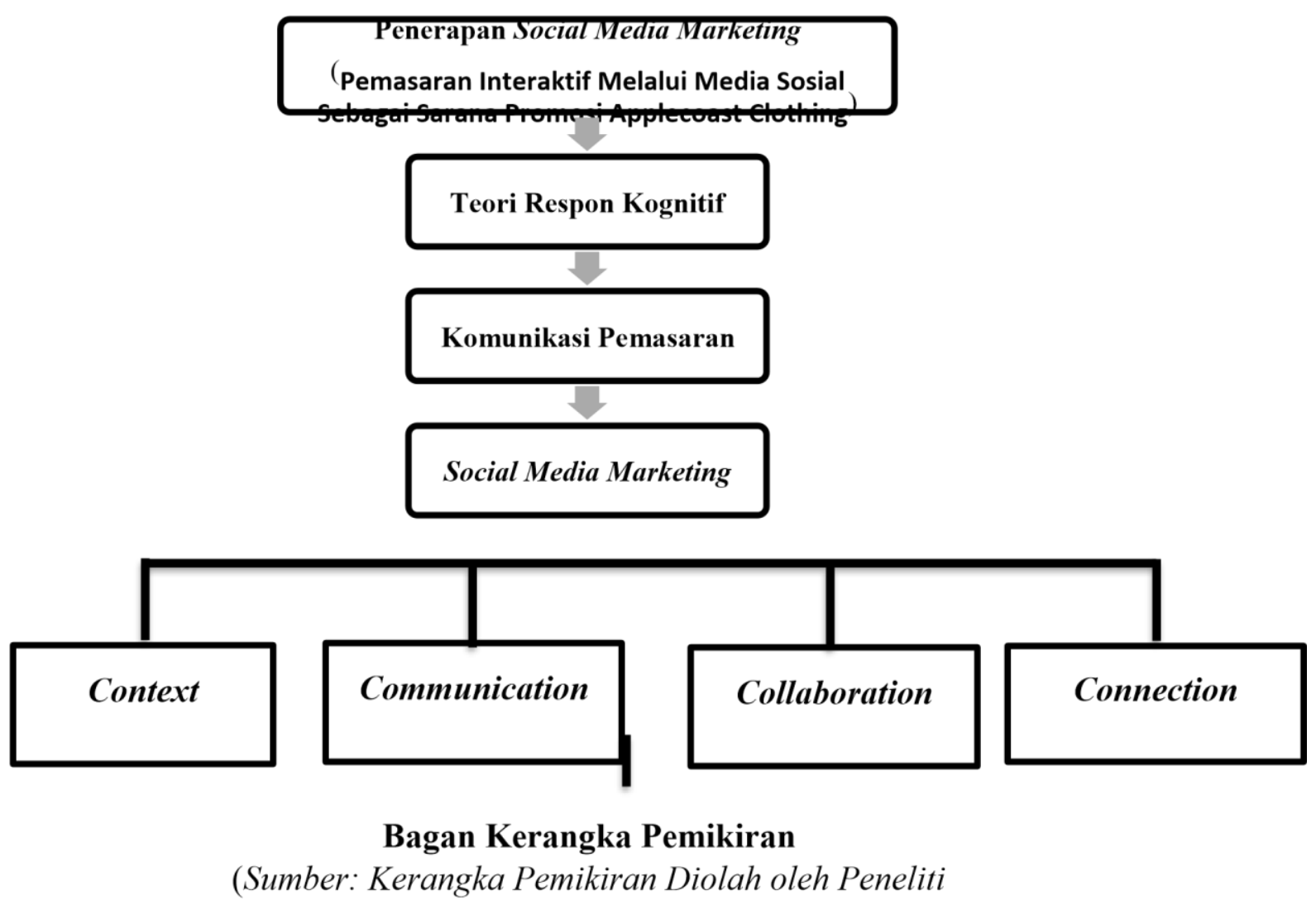

\section{Metode Populasi}

Populasi merupakan wilayah generalisasi yang terdiri atas: objek/subjek yang mempunyai kuantitas dan karakteristik tertentu yang ditetapkan oleh periset untuk dipelajari. (Sugiyono 2013: 117). Dalam penelitian ini, populasinya adalah masyarakat Bandung yang merupakan followers atau pengikut dari akun Instagram @ applecoast yang berjumlah kurang lebih 11.700 pengikut (per 30 November 2019).

\section{Sampel}

Sampel adalah bagian dari jumlah dan karakteristik yang dimiliki oleh populasi tersebut. Sampel merupakan suatu bagian dari populasi yang ingin diteliti (Priyono 2016: 104). Penarikan sampel yang digunakan peneliti merupakan bentuk Systematic Sampling atau Sampel Sistematis, merupakan cara pengambilan sampel yang sampel pertamanya ditentukan secara acak, sedangkan sampel berikutnya diambil berdasarkan satu interval tertentu. Dalam Systematic Random Sampling, responden yang terpilih menjadi sampel merupakan hasil pengambilan secara acak sistematis. Cara ini dilakukan dengan cara menggunakan interval tertentu dalam menentukan anggota sampel yang ke-n yaitu dilakukan penambahan dengan interval tersebut untuk menetapkan anggota sampel berikutnya, begitulah seterusnya sampai jumlah sampel terpenuhi. 

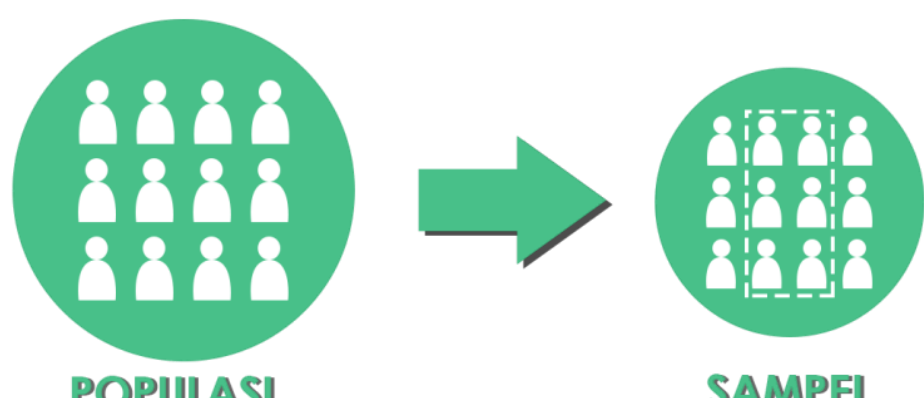

SAMPEL

Gambar 2. Hubungan Populasi dan Sampel

(Sumber: Dr. Deni Darmawan, S.Pd., M.Si 2013: 146)

Untuk menentukan besaran sampel pada penelitian ini, penulis menggunakan Rumus Yamane. Menurut Rakhmat (2014: 82), rumus ini rumus yang sederhana. Untuk menentukan jumlah sampel dari populasinya dapat dilakukan melalui rumus Yamane sebagai berikut :

$$
\mathrm{n}=\frac{N}{N d^{2}+1}
$$

Keterangan:

$\mathrm{n}=$ Berapa besar sampel yang diperlukan

$\mathrm{N}=$ Populasi

$\mathrm{d} 2=$ Presisi yang diinginkan

kesalahan atau ketidaktelitian yang dinyatakan dengan persentase. Semakin kecil toleransi kesalahan, semakin akurat sampel menggambarkan populasi. Misalnya penelitian dengan batas kesalahan $10 \%$ berarti memiliki tingkat akurasi sebesar 90\%. dengan jumlah populasi yang sama, semakin kecil toleransi kesalahan, semakin besar jumlah sampel yang dibutuhkan.

Dalam penelitian ini, penulis menggunakan $10 \%$ dan akurasi $90 \%$ dengan jumlah populasi sebanyak 11.700 responden. Maka, dalam penerapan rumus Yamane penelitian yang dilakukan sebagai berikut:

$$
\begin{aligned}
& n=\frac{11.700}{11.700(0,1)^{2}+1} n \\
& =\frac{11.700}{11.700(0,01)+1} \\
& n=\frac{11.700}{117+1} n \\
& =\frac{11.700}{118} \\
& n=99.15 n \\
& =100
\end{aligned}
$$




\section{Teknik Analisis Data}

Teknik analisis data merupakan salah satu proses penelitian yang dilakukan setelah semua data yang diperlukan guna memecahkan permasalahan yang diteliti sudah diperoleh secara lengkap. Teknik analisis data akan menjelaskan langkahlangkah peneliti dalam mengolah data yang didapatkan dilapangan menjadi sebuah laporan hasil penelitian.

Metode analisis deskriptif merupakan suatu rumusan masalah yang berkenaan dengan pertanyaan terhadap keberadaan variable mandiri, baik hanya pada satu variabel atau lebih (variabel mandiri adalah variabel yang berdiri sendiri, bukan variabel independen, karena kalau variabel independen selalu dipasangkan dengan variabel dependen) (Sugiyono 2014: $53)$.

\section{Hasil Penelitian dan Pembahasan}

\section{Efektivitas Penerapan 4C Sosial Media Marketing}

Berikut adalah hasil penelitian mengenai efektivitas pnerapan 4C sosial media marketing.

Tabel 1. Hasil Persentase variable 4C

\begin{tabular}{|c|c|c|c|}
\hline No & Indikator & & Kategori \\
\hline 1. & Context & Total Skor Terbanyak & \\
\hline 2. & Communication & 45 & Kurang Baik \\
\hline 3. & Collaboration & 41 & Cukup Baik \\
\hline 4. & Connection & & Cukup Baik \\
\hline & & & Cukup Baik \\
\hline
\end{tabular}

Kegiatan pemasaran dan promosi yang dilakukan Applecoast menggunakan media sosial instagram dan website. Dalam kegiatan tersebut penerapan 4C di media sosial dan website ini terus dilaksanakan dan dikembangkan oleh Applecoast agar kegiatan promosinya dapat berjalan dengan lancar dan efektif, dapat mendapatkan lebih banyak konsumen dan tetap dapat memelihara hubungan baik dengan konsumen yang sebelumnya sudah terjalin.

Promosi merupakan usaha dalam mengenalkan dan sekaligus membujuk calon konsumen untuk mengenal dan menggunakan produk yang ditawarkan (Munazar\&Chaerowati, 2019 877)

Berdasarkan hasil tabel diatas, dapat diketahui bahwa penerapan context atau penggunaan bahasa dalam proses penyampaian pesan yang dilakukan oleh Applecoast berada pada kategori kurang baik atau dalam kata lain Applecoast dalam penggunaan bahasa dalam proses penyampaian pesan belum maksimal dilakukan. Penerapan communication atau 
penyampaian informasi dan pengemasan sebuah pesan yang diberikan di media sosial oleh Applecoast berada pada kategori cukup baik atau dapat dikatakan bahwa penyampaian informasi dan pengemasan sebuah pesan yang diberikan mampu menarik minat konsumen dikarenakan penyampaian informasi yang diberikan sesuai dengan kebutuhan konsumen, content media sosialnya menarik, dan katalog produknya lengkap. Penerapan collaboration atau bentuk kerja sama dan tanggapan yang diberikan Applecoast di media sosial berada kategori cukup baik dengan kata lain dapat berjalan sesuai dengan yang diharapkan. Applecoast mampu berkomunikasi dengan baik dengan konsumennya, dan mampu merespon dengan baik konsumennya. Penerapan connection atau cara memelihara hubungangan yang sudah terjalin sebelumnya dengan konsumen merupakan hal yang sangat penting agar konsumen percaya dan tidak berpaling. Hal tersebut sudah terlaksana dengan cukup baik, Applecoast mampun menanggapi keluh kesah konsumennya, memberikan apresiasi dengan cara memberikan diskon, dan menampilkan review (testimonial) dari konsumen yang pernah melakukan pembelian. Dan indokator ini berada pada kategori cukup baik. Hal-hal tersebut didapatkan berdasarkan hasil dari perhitungan angket yang diperoleh yang telah disebar sebelumnya.

\section{Kesimpulan}

Berdasarkan pembahasan dalam penelitian ini, peneliti menyimpulkan beberapa hasil penelitian sebagai berikut:

1. Applecoast menggunakan Instagram dan website sebagai alat promosi melalui media soial

2. Penerapan context atau penggunaan bahasa dalam penyampaian pesan dan informasi yang diberikan di instagram merupakan salah satu faktor penting dalam kegiatan promosi, karena akan mempermudah konsumen dalam memahami informasi yang disampaikan. Namun, Applecoast belum mampu menerapkan context dengan baik atau penggunaan bahasa dalam menyampaikan sebuah pesan dan informasi belum maksimal dan berdasarkan hasil perhitungan berada pada kategori kurang baik.

3. Penerapan communication atau penyampaian informasi dan pengemasan sebuah pesan yang diberikan di instagram oleh Applecoast dapat menarik minat konsumen. Berdasarkan hasil penelitian diketahui bahwa penyampaian informasi dan pengemasan sebuah pesan yang diberikan mampu menarik minat konsumen dikarenakan penyampaian informasi yang diberikan sesuai dengan kebutuhan konsumen, content media sosialnya menarik, dan katalog produknya lengkap, berdasarkan hasil perhitungan berada pada kategori cukup baik.

4. Penerapan collaboration atau bentuk kerja sama dan tanggapan yang diberikan Applecoast di instagram berjalan sesuai dengan yang diharapkan. Applecoast mampu berkomunikasi dengan baik dengan konsumennya, dan mampu merespon dengan baik konsumennya. Dan berdasarkan hasil perhitungan berada pada kategori cukup baik.

5. Penerapan connection atau cara memelihara hubungangan yang sudah terjalin sebelumnya dengan konsumen merupakan hal yang sangat penting agar konsumen percaya dan tidak berpaling. Hal tersebut sudah terlaksana dengan cukup baik, Applecoast mampu menanggapi keluh kesah konsumennya, memberikan apresiasi dengan cara memberikan diskon, dan menampilkan review (testimonial) dari konsumen yang pernah melakukan pembelian. Dan berdasarkan hasil perhitungan berada pada kategori cukup baik.

\section{E. Saran}

1. Dari hasil penelitian yang peneliti lakukan dengan judul "Pemasaran Interaktif Melalui Media Sosial Sebagai Sarana Promosi Applecoast Clothing" diharapkan dapat menambah pengetahuan secara akademis dengan konsep-konsep dan teori-teori yang terkait dengan ilmu komunikasi

2. Kepada peneliti lain yang akan meneliti mengenai komunikasi pemasaran khususnya 
mengenai pemasaran dan promosi melalui media sosial dapat mengangkat tema yang berbeda dengan penelitian ini dan dapat lebih mengembangkan jika ingin meneliti mengenai pemasaran dan promosi melalui media sosial, sehingga dapat dikaji temuantemuan baru mengenai kegiatan pemasaran dan promosi melalui media sosial dan komunikasi pemasaran.

3. Hendaknya pihak manajemen Applecoast dalam mempromosikan produkproduknya memberikan penjelasan yang secara detail terutama mengenai bahasa iklan serta informasi harus dapat dipahami oleh khalayak.

4. Penjelasan mengenai produk harus sesuai dengan foto yang ditampilkan, agar para peminat atau para pembeli tidak merasa kecewa setelah melihat serta akan membeli produk yang diinginkan setelah melihat foto serta caption di media sosial Applecoast.

5. Diharapkan hasil penelitian ini memberikan gambaran bagi mahasiswa yang ingin memulai berbisni bagaimana salah satu cara menggunakan media sosial sebagai media pemasaran dan promosi.

\section{Daftar Pustaka}

[1] Effendy, Onong Uchjana. 2016. Dinamika Komunikasi. Bandung: PT. Remaja Rosdakarya.

[2] Fandy Tjiptono, Ph.D. 2015. Strategi Pemasaran, Edisi 4, Penerbit Andi, Yogyakarta.

[3] Ferni Fera Ch. Wolah. 2016. Peranan Promosi Dalam Meningkatkan Kunjungan

Wisatawan Di Kabupaten Poso. e-journal “Acta Diurna” Volume V. No.2. Tahun 2016.

[4] Rosmawan, Ryan. 2016. Hubungan Penyajian Pesan Pada Situs Traveloka Dengan Proses Pengambilan Keputusan Konsumen Membeli Tiket Pesawat Dan Hotel.Fakultas Ilmu Komunikasi Universitas Islam Bandung.

[5] Munazar R, M.Andara \& Chaerowati, Dede Lilis 2019. Promosi Dalam Elektronic

Word Of Mouth pada Posting Instagram.

http://karyailmiah.unisba.ac.id/index.php/mankom/article/view/19128

[6] Tjiptono, Fandi. 2015. Strategi Pemasaran (Edisi 4). Yogyakarta: ANDI

[7] Indika, Deru \& Jovita, Cindy. 2017. “ Media Sosial Instagram Sebagai Sarana Promosi Untuk Meningkatkan Minat Beli Konsumen ", dalam Jurnal Bisnis Terapan Vol.01, No.1, 1 Juni 2017 ( hal 27)

[8] Sugiyono. 2013. Metode Penelitian Pendidikan: Pendekatan Kuantitatif, Kualitatif, dan R\&D. Bandung: Alfabeta.

[9] Sugiyono. 2015. Metode Penelitian Pendidikan: Pendekatan Kuantitatif, Kualitatif, dan R\&D. Bandung: Alfabeta 